\title{
NORTH AND SOUTH: THE DISPARATE LEGAL APPROACHES TO HOMOSEXUAL ACTIVITY IN THE UNITED STATES AND NICARAGUA
}

\author{
Bethany Williams*
}

The makers of our Constitution undertook to secure conditions favorable to the pursuit of happiness. They recognized the significance of man's spiritual nature, of his feelings and of his intellect. . . . They sought to protect Americans in their beliefs, their thoughts, their emotions and their sensations. They conferred, as against the Government, the right to be let alone - the most comprehensive of rights and the right most valued by civilized men. ${ }^{1}$

The legislation of our country cannot be made for the pleasure or satisfaction of a small group of ideologues or practitioners of sodomy. The Commission of this Assembly that reported out the proposed law to reform the penal code consulted the most diverse sectors of Nicaraguan society, and their general opinion was to condemn and penalize the scandalous practice and the propaganda of unnatural sexual conduct. ${ }^{2}$

\section{INTRODUCTION}

The topic of homosexual activity, specifically the right to participate in sodomy, is one of the most hotly debated topics both in the United States and abroad. Vastly disparate approaches to this topic have been taken in the United States and in Nicaragua.

The United States' approach toward homosexual activity has become increasingly liberal. ${ }^{3}$ In the past ten years, even the nine states steadfastly maintaining statutes that criminalize homosexual activity, specifically sodomy, have begun to repeal the statutes in landmark decisions. ${ }^{4}$ These decisions culminated in the Lawrence $v$. Texas decision on June 26,2003 . $^{5}$ The decisions

* J.D. Indiana University School of Law - Indianapolis, 2005 (expected); B.A. Indiana University, 1997. The author would like to thank Rochelle who has always acted as her compass and never steered her wrong.

1. Olmstead v. United States, 277 U.S. 438, 478 (1928) (Brandeis, J., dissenting).

2. Martha I. Morgan, The Bitter and the Sweet: Feminist Efforts to Reform Nicaraguan Rape and Sodomy Laws, 26 U. MIAMI INTER-AM. L. REV. 439, 468 (1995) (quoting Alfredo Cesar, President of the Nicaraguan National Assembly).

3. See infra Part II.D.

4. See infra Part II.E.

5. Lawrence v. Texas, 539 U.S. 558 (2003). This case overturned Bowers v. Hardwick, 
in the United States have predominantly focused on the right to privacy in sexual activities. ${ }^{6}$ In deciding Lawrence, the Court stated, "Our obligation is to define the liberty of all, not to mandate our own moral code."7

In contrast to this broadening of legally acceptable homosexual activities in the United States, Nicaragua has been moving in the opposite direction. ${ }^{8}$ In 1992, a proposal was made during a session of the Nicaraguan Assembly that Article 205 of the 1974 Penal Code, which prohibited practicing homosexual activity in a "scandalous manner," be deleted." Instead, Article 205 was actually broadened to include not just the practice of homosexual behavior, but "inducing, promoting or propagandizing" homosexual behavior. ${ }^{10}$ A challenge was raised to this broadening of the penal code, but it was cursorily denied and the Nicaraguan court ruled that the "sin is the scandal."

Both the United States and Nicaragua make a connection between privacy and the practice of homosexual activities. The United States' repeal of statutes precluding homosexual activity is based upon Fourth and Fourteenth Amendment rights to privacy. ${ }^{12}$ Nicaragua, in broadening its penal code, continues to focus on the "publicity" or "scandalous nature" of homosexual activity. ${ }^{13}$ Despite the interest in both privacy and publicity, the two countries come to very different conclusions. These diametric positions are interesting in and of themselves and, given the latest decision in Lawrence, as well as the growing Nicaraguan population in the United States, germane and topical. ${ }^{14}$

Part II of this Note will discuss the evolution of the right to privacy in the United States as it relates to all sexual matters - not just the practice of homosexual activity. It will examine the gradual movement and evolution of the right to privacy in sexual matters and its abrupt halt with the Bowers $v$. Hardwick decision, which relates specifically to homosexual activity. ${ }^{15}$ Part II

478 U.S. 186 (1986). See infra Part II.C. Bowers held that there was no constitutional right for adult homosexuals to commit consensual sodomy, even in the privacy of their own homes. See infra Part II.B.

6. See infra Part II.E-F.

7. Lawrence, 539 U.S. at 571 (quoting Planned Parenthood of Southeastern Pa. v. Casey, 505 U.S. 833, 850 (1992)).

8. See infra Part III.

9. Morgan, supra note 2, at 446.

10. Id. at 447.

11. Id. at 468 .

12. See infra Part II.E-F.

13. Morgan, supra note 2 , at $468-69$.

14. ProNicaragua (untitled document), at http://anitec.net/pronica2.htm (n.d.) (last visited Aug. 6, 2004). "Nicaraguans in the United States have reached substantial numbers in most urban areas . . . ." Id. "Since the 1970s, several civil wars, along with economic turmoil in Latin American countries brought substantial numbers of immigrants ... to the United States. This includes 800,000 Nicaraguans . . . Commission on Professionals in Science and Technology, Limited Progress: The Status of Hispanic Americans in Science, Engineering, at http://www.cpst.org/web/site/pages/pubs/Hispanics/hispanics.htm (n.d.) (last visited Oct. 21, 2004).

15. See Bowers v. Hardwick, 478 U.S. 186 (1986), overruled by Lawrence v. Texas, 539 U.S. 558 (2003). 
will then explore the statutes in various states criminalizing homosexual activity and their purported purposes, briefly discuss the general bias against homosexuals in the United States, and ways in which the United States has attempted to "legislate morality." Finally, Part II will trace the repeals of statutes criminalizing homosexual activity in various states, culminating in the most recent decision in Lawrence $v$ Texas in June, 2003. ${ }^{16}$

Part III of this Note will address the existence of a right to privacy and the "moral majority" in Nicaragua. The intended purpose of the original 1974 Penal Code in Nicaragua, specifically Article 205, will be examined, as well as the broadening of the Article during the 1992 Assembly Session and the ways in which the expansion may touch the lives of homosexuals and others in Nicaragua. Consideration will be given to several influential traditions and trends in Nicaragua, reflected in the broadening of the penal code. Part III will also examine the adjudication of morality in Nicaragua and how that adjudication led to the failure of the challenge to the broadening of the penal code.

Part IV of this Note will provide some brief reflections on the international arena and will endeavor to present some examples of the various ways that other countries are dealing with the issue of legalizing (or not legalizing) homosexual activity. This section of the Note is intended to present some brief examples of the assorted methods by which members of the international community address the treatment of homosexual activities.

In conclusion, Part $\mathrm{V}$ will offer some general observations on the policies in effect in both the United States and Nicaragua. Concerns and questions regarding the future of this issue in each country will be considered. Finally, a brief mention will be made of the ironically similar results.

\section{THE EVOLUTION OF THE RIGHT TO PRIVACY IN THE UNITED STATES}

\section{A. The Evolution of the Right to Privacy Relating to Sexual Matters Not Encompassing Homosexual Activity}

Although the Constitution "does not explicitly mention any right of privacy ... the Court has recognized that a right of personal privacy, or a guarantee of certain areas or zones of privacy, does exist under the Constitution." 17 This right can be found in the "penumbras of the Bill of Rights, ... in the Ninth Amendment, . . . or in the concept of liberty guaranteed by the first section of the Fourteenth Amendment." 18

In Griswold v. Connecticut, ${ }^{19}$ Griswold appealed his conviction under a statute providing for fines and/or imprisonment of individuals dispensing "any

16. See Lawrence, 539 U.S. 558 (2003).

17. Roe v. Wade, 410 U.S. 113, 152 (1973).

18. Id.

19. Griswold v. Connecticut, 381 U.S. 479 (1965). 
drug, medicinal article or instrument for the purpose of preventing conception."20 The appellant had advised married individuals in the use of contraceptive devices. ${ }^{21}$ The Griswold Court stated that the Fourth Amendment "affirms the 'right of the people to be secure in their persons, houses, papers, and effects against unreasonable searches and seizures.",22 The Court further found that the Fifth Amendment "enables the citizen to create a zone of privacy which government may not force him to surrender to his detriment.",23

The Griswold Court held that the marital relationship lies "within the zone of privacy created by several fundamental constitutional guarantees."24 The Court further found that marriage was a "right of privacy older than the Bill of Rights" and responded to the question of whether the Court would "allow the police to search the sacred precincts of marital bedrooms for telltale signs of the use of contraceptives" with the answer that " $t]$ he very idea is repulsive." 25

In making this decision, the Court referred to precedent establishing a certain level of liberty within the "private realm of family life[,]"26 such as was established in Pierce v. Society of Sisters ${ }^{27}$ and Meyer v. Nebraska. ${ }^{28}$ Having established this level of privacy in the realm of family life, the Court stated that it was "difficult to imagine what is more private or more intimate than a husband and wife's marital relations."29

The Court reminded the parties that it was well established that a state could make a significant encroachment upon personal liberty only when the state could "show[] a subordinating interest which is compelling."30 The Griswold Court refused to accept the State's argument that the statute would help "prevent the indulgence by some in ... extra-marital relations." 31 Having declared the statute to be an unacceptable way for the State to express its interest in safeguarding fidelity and having determined that the statute infringed upon the privacy of the marital relationship, the statute was found unconstitutional and in violation of the Fourth Amendment. ${ }^{32}$

20. Conn. Gen. Stat. § 53-32 (1958).

21. Griswold, 381 U.S. at 480.

22. Id. at 484 (citing U.S. CoNST. amend. IV).

23. Id. at 480 .

24. Id. at 485 .

25. Id. at 485-86.

26. Id. at 495 (quoting Prince v. Massachusetts, 321 U.S. 158, 166 (1944)).

27. 268 U.S. 510 (1925). The Court found an Oregon Act forbidding parents to send their children to private schools to "unreasonably [interfere] with the liberty of parents and guardians to direct the upbringing and education of children under their control." ld. at 534-35.

28. 262 U.S. 390 (1923). The Court found that the right "to marry, establish a home and bring up children" was guaranteed under the Fourteenth Amendment. Id. at 399.

29. Griswold, 381 U.S. at 495.

30. Id. at 497 (quoting Bates v. Little Rock, 361 U.S. 516, 524 (1960)).

31. Id. at 498.

32. Id. at 485-86. 
The Court's decision in Griswold helped pave the way for acknowledgment of a sphere of privacy surrounding sexual matters. While Griswold only applied to the use of contraceptive devices by married couples, less than ten years later the Court enlarged that sphere of privacy and the conception of the right to privacy. ${ }^{33}$

Eisenstadt $v$. Baird expanded the right to use contraceptive devices to unmarried people. ${ }^{34}$ The appellant was convicted of providing vaginal foam to an unmarried woman at the end of a lecture. ${ }^{35}$ The distribution of the contraceptive foam was in violation of Massachusetts law ${ }^{36}$, which forbade the distribution of contraceptive devices to anyone not acting in accordance with the terms of Massachusetts General Law. ${ }^{37}$

The Eisenstadt Court found that "[i]f the right of privacy means anything, it is the right of the individual, married or single, to be free from unwarranted governmental intrusion into matters so fundamentally affecting a person as the decision whether to bear or beget a child." ${ }^{38}$ The Court further agreed with the

33. See Eisenstadt v. Baird, 405 U.S. 438 (1972).

34. Id.

35. Id. at 440.

36. MASS. GEN. LAwS ANN. ch. $272 \S 21$ (West 1966) provided in full:

Except as provided in section twenty-one A, whoever sells, lends, gives away, exhibits or offers to sell, lend or give away an instrument or other article intended to be used for self-abuse, or any drug, medicine, instrument or article whatever for the prevention of conception or for causing unlawful abortion, or advertises the same, or writes, prints, or causes to be written or printed a card, circular, book, pamphlet, advertisement or notice of any kind stating when, where, how, of whom or by what means such article can be purchased or obtained, or manufactures or makes any such article shall be punished by imprisonment in the state prison for not more than five years or in jail or the house of correction for not more than two and one half years or by a fine of no less than one hundred not more than one thousand dollars.

37. MASS GEN. LAW ANN. ch. $272 \S 21$ (a) (1966) provided in full:

A registered physician may administer to or prescribe for any married person drugs or articles intended for the prevention of pregnancy or conception. A registered pharmacist actually engaged in the business of pharmacy may furnish such drugs or articles to any married person presenting a prescription from a registered physician.

A public health agency, a registered nurse, or a maternity health clinic operated by or in an accredited hospital may furnish information to any married person as to where professional advice regarding such drugs or articles may be lawfully obtained.

This section shall not be construed as affecting the provisions of sections twenty and twenty-one relative to prohibition of advertising of drugs or articles intended for the prevention of pregnancy or conception; nor shall this section be construed so as to permit the sale or dispensing of such drugs or articles by means of any vending machine or similar device.

38. Eisenstadt, 405 U.S. at 453. 
appellate court's assessment that such a legislative plan "conflicts with fundamental human rights." 39

Like the Griswold Court, the Eisenstadt Court considered whether or not the State had the requisite compelling interest to allow intervention in such private matters. ${ }^{40}$ The Court noted that the "legislative purposes that the statute is meant to serve are not altogether clear." previous cases and determined that the State of Massachusetts intended to prevent the distribution of contraceptive devices that might be dangerous as well as "protect morals through 'regulating the private sexual lives of single persons." 42 The Court determined that the statute's purpose could not be reasonably regarded as the deterrence of premarital sex. ${ }^{43}$ Neither could the statute be reasonably regarded as a health measure. ${ }^{44}$

Eisenstadt further expanded the sphere of privacy in sexual relations by acknowledging that not only married individuals, but also unmarried individuals, had a right to privacy in their sexual relations. ${ }^{45}$ Roe v. Wade expanded the right to privacy even further with its decision legalizing abortion in $1973 .{ }^{46}$

The "principle thrust" of the attack on the statute preventing legal access to an abortion was appellant's contention that the statute violated "the concept of personal 'liberty' embodied in the Fourteenth Amendment[] . . . in personal, marital, familial, and sexual privacy said to be protected by the Bill of Rights or its penumbras . ..."47 The Court determined that the statute, which made no exception for incidents where the mother's life was at stake, swept "too broadly" and could not "survive the constitutional attack . . . upon it . . .,"48

Who is entitled to privacy in their sexual relations was further expanded in Carey v. Population Services Int' . $^{49}$ This case challenged the constitutionality of a New York law prohibiting, in part, the sale of contraceptives to minors. ${ }^{50}$ In deciding Carey, the Court reiterated that "[a]lthough '[t]he Constitution does not explicitly mention any right of

39. Id. at 453.

40. Id. at 448 .

41. Id. at 442 .

42. Id. (quoting Sturgis v Attorney General, 260 N.E.2d 687, 690 (1970)).

43. Id. at 448 .

44. Id. at 452 .

45. Id. at 454.

46. Roe v. Wade, 410 U.S. $113,164-65$ (1973).

47. Id. at 129.

48. Id. at 164 .

49. Carey v. Population Serv. Int'1, Inc., 431 U.S. 678 (1977).

50. N.Y. EDUC. LAW $\S 6811(8)$ (1972), makes it a class A misdemeanor for:

Any person to sell or distribute any instrument or article, or any recipe, drug or medicine for the prevention of conception to a minor under the age of sixteen years; the sale or distribution of such to a person other than a minor under the age of sixteen years is authorized only by a licensed pharmacist but the advertisement or display of said articles, within or without the premises of such pharmacy, is hereby prohibited. 
privacy,' the Court has recognized that one aspect of the 'liberty' protected by the Due Process Clause of the Fourteenth Amendment is 'a right of personal privacy, or a guarantee of certain areas or zones of privacy." "51 The Court then recounted the numerous previous decisions giving individuals the "interest in independence in making certain kinds of important decisions," 52 including "marriage, ... procreation, ... contraception, ... [ [and] family relationships." Finally, the Court held that "the right to privacy in connection with decisions affecting procreation extends to minors as well as to adults."

Carey demonstrated the Court's increased willingness to expand the sphere of privacy found around the sexual relations of individuals and further restricted attempts of the State to "legislate morality." By acknowledging minors' rights to privacy in sexual matters, the Court created the impression that the right to privacy in sexual matters was for everyone, until its decision in Bowers v. Hardwick. ${ }^{55}$

\section{B. Drawing the Line: The Bowers v. Hardwick Decision}

After the Griswold, Eisenstadt, Roe, and Carey decisions, the Court seemed to have successfully "delinked" the constitutional protection of privacy in sexual matters from procreation. ${ }^{56}$ The Court's previous decisions created a sliding scale of protection for various sexual activities. ${ }^{57}$ By the time of the Bowers decision, the Court had granted its protection to "nonprocreative contraceptive marital intercourse; nonprocreative contraceptive nonmarital intercourse; abortion; and non-nuclear family living arrangements." ${ }^{\text {,5 }}$ The Court had refused to protect incest, commercial sex, intergenerational sex and forcible sex. ${ }^{59}$

In reviewing this laundry list of sexual rights, it would seem that homosexual activity would fall closer to the protected categories of non-nuclear family living arrangements and non-procreative, non-marital intercourse than to commercial sex or forcible sex. However, Bowers dispelled any illusion held

51. Carey, 431 U.S. at 684 (quoting Roe v. Wade, 410 U.S. 113, 152 (1973)).

52. Id.at 684 (quoting Whalen v. Roe, 429 U.S. 589, 599-600 (1977)).

53. Id. at 685 .

54. Id. at 693 .

55. See Bowers v. Hardwick, 478 U.S. 186 (1986) (holding that homosexuals had no constitutional right to practice sodomy); see also infra Part II.B.

56. William N. Eskridge, Jr., Hardwick and Historiography, 1999 U. ILL. L. REV. 631, 638 (1999).

57. See Griswold v. Connecticut, 381 U.S. 479 (1965) (holding that married heterosexuals had a constitutional right to the use of contraceptive devices); Eisenstadt v. Baird, 405 U.S. 438 (1972) (holding that unmarried heterosexuals had a constitutional right to use contraceptive devices); Roe v. Wade, 410 U.S. 113 (1973) (holding that a woman has a constitutional right to terminate a pregnancy through abortion); Carey, 431 U.S. 678 (holding that minors have a constitutional right to access contraceptive devices).

58. Eskridge, supra note 56, at 640.

59. Id. at 640-41. 
by the gay community in the United States that they too were moving toward a greater equality ${ }^{60}$ Bowers made it very clear that the Court had finally found a clear line to delineate between "acceptable" and "unacceptable" sexual activities, and that homosexual activity would not fall into a protected sphere of privacy. ${ }^{61}$ In rendering the decision in Bowers, Justice White referred to Hardwick's fundamental rights claim as "at best, facetious" 62 and found that there was a basis in a "presumed belief of a majority of the electorate in Georgia that homosexual sodomy is immoral and unacceptable."

In Bowers, "Bowers . . . and . . . Hardwick . . . were forever joined as a couple" when Hardwick challenged the constitutionality of Georgia's application of its criminal sodomy law to consensual oral sex between two adult men. ${ }^{64}$ Hardwick was charged with violating the Georgia statute ${ }^{65}$ criminalizing sodomy by engaging in what the Court referred to as "that activity" in his own bedroom. ${ }^{66}$ Hardwick sued in federal court, challenging the constitutionality of the statute. ${ }^{67}$ Hardwick "asserted that he was a practicing homosexual" and that the statute, "as administered by the defendants, placed him in imminent danger of arrest, and that the statute ... violate[d] the Federal Constitution." 68

The court of appeals reversed the district court and held that the statute "violated respondent's fundamental rights because his homosexual activity is a private and intimate association that is beyond the reach of state regulation by reason of the Ninth Amendment and the Due Process Clause of the Fourteenth Amendment." 69 The Supreme Court reversed the court of appeals' decision. ${ }^{70}$

The Court narrowed the issue in Bowers to the question of whether the Constitution created a "fundamental right upon homosexuals to engage in sodomy and hence invalidates the laws of the many States that still make such conduct illegal and have done so for a very long time." ${ }^{21}$ If one merely examined how the Court framed the issue, it would be entirely possible, without

60. See Bowers, 478 U.S. 186 (1986).

61. See generally id.

62. Id. at 194.

63. Id. at 196.

64. Eskridge, supra note 56 , at 632.

65. GA. CODE ANN. § 16-6-2 (1984) provided in pertinent part:

A person commits the offense of sodomy when he or she performs or submits to any sexual act involving the sex organs of one person and the mouth or anus of another...

A person convicted of the offense of sodomy shall be punished by imprisonment for not less than one nor more than 20 [sic] years....

This was held to be unconstitutional in 1998 by Powell v. State, 510 S.E.2d (Ga. 1998).

66. Bowers, 478 U.S. at $187-88$.

67. Id. at 188 .

68. Id.

69. Id. at 189 .

70. Id.

71. Id. at 190. 
reading the remainder of the opinion, to accurately imagine the Court's final ruling in this matter. ${ }^{72}$

The Court immediately discarded the idea that any of the cases establishing an area of privacy in sexual matters were related to this matter. ${ }^{73}$ The Court stated there was "[n]o connection between family, marriage, or procreation ... and homosexual activity ...."74 The Court went on to say that "any claim that these cases ... stand for the proposition that any kind of private sexual conduct between consenting adults is constitutionally insulated from state proscription is unsupportable." ${ }^{75}$ In making its decision, the Court relied heavily upon the idea that there are "ancient roots" to proscriptions against homosexual conduct. ${ }^{76}$ The Court then proceeded through a heavily biased, and arguably revisionist, history of the United States' laws against homosexual conduct. ${ }^{77}$

The Court disposed of the respondent's claim that consensual homosexual activity, even if not condoned by law, should not be prosecuted when it occurred in the privacy of one's home with the assertion that "[v]ictimless crimes . . . do not escape the law where they are committed at home." to such "victimless crimes" as the use of illegal drugs. ${ }^{79}$ In an astounding leap, the Court also compared consensual homosexual activity between adults to other reviled and criminal sexual acts committed in the home such as incest. ${ }^{80}$

Finally, in determining whether or not there was a rational basis for such a law in Georgia, the Court returned to its perch on the moral high ground and proselytized that the law was based upon the "belief of a majority of the electorate in Georgia that homosexual sodomy is immoral and unacceptable."

\section{Legalized Discrimination: State Statutes Criminalizing Consensual Homosexual Activity}

After the Bowers decision, three states made consensual sodomy a crime only for same-sex partners, adding their numbers to the seven states with such laws already on their books. ${ }^{82}$ Montana's statute was instituted in 1973, prior to

72. Eskridge, supra note 56 , at 683 . "There are some ways of framing the question that are less neutral than others, however. The exemplar of non-neutrality is the way Justice White set the originalist inquiry ...." Id.

73. Bowers, 478 U.S. at 190.

74. Id. at 191.

75. Id.

76. Id. at 192.

77. See generally Eskridge, supra note 56.

78. Bowers, 478 U.S. at 195.

79. Id.

80. Id. at 196.

81. Id.

82. Eskridge, supra note 56, at 633. Prior to the Bowers v. Hardwick decision, seven states had statutes making homosexual activity a crime. Those seven states were Arkansas 
the Bowers decision, as part of a revision of criminal law. ${ }^{83}$ Prior to the revision, the statute had proscribed "crimes against nature" with persons or animals, rather than specifying activity between individuals of the same sex. ${ }^{84}$ The revised statute, under Section 45-5-505(1), provided that a "person who knowingly engages in deviate sexual relations or who causes another to engage in deviate sexual relations commits the offense of deviate sexual conduct." 85 The term "deviate sexual relations" is defined as "sexual contact or sexual intercourse between two persons of the same sex or any form of sexual intercourse with an animal."

Kentucky instituted its statute barring homosexual conduct in 1974. this statute, Section 510.100, prohibited "deviate sexual intercourse with another person of the same sex" and specified that the "consent of the other person shall not be a defense." 87

Arkansas' statute prohibiting sodomy specifically between persons of the same sex was instituted in 1977 under Section 5-14-122 and stated as follows:

(a) A person commits sodomy if such person performs any act of sexual gratification involving:

(1) The penetration, however slight, of the anus or mouth of an animal or a person by the penis of a person of the same sex or an animal; or

(1977), Kansas (1969), Kentucky (1974), Missouri (1977), Montana (1973), Nevada (1977), and Texas (1973). The three states that instituted new statutes after the decision were Okalahoma (judicial decision, 1986), Tennessee (1989), and Maryland (judicial decision, 1990). Courts in Kentucky, Montana, Tennessee, and Arkansas later struck down the laws because the statutes were determined to violate privacy rights granted by the States' constitutions. For the purposes of this Note, the decisions in Tennessee, Arkansas, Kentucky, and Montana will be discussed. A subsequent repeal in Nevada will not be discussed. The prohibitive statute in Texas was struck in federal court and will be discussed separately from the state court rulings in Arkansas, Montana, Tennessee, and Kentucky. Id.

83. Gryczan v. State, 942 P.2d 112, 116 (Mont. 1997).

84. Id.

85. MONT. CodE ANN. § 45-5-505(1) (1973).

86. "Sexual contact" is defined by MONT. CODE ANN. § 45-2-101(65) (1973) as: "[A]ny touching of the sexual or other intimate parts of the person of another for the purpose of arousing or gratifying the sexual desire of either party." Sexual intercourse" is defined by MONT. CODE ANN. § 45-2-101(66) as:

[P]enetration of the vulva, anus, or mouth of one person by the penis of another person, penetration of the vulva or anus of one person by any body member of another person, or penetration of the vulva or anus of one person by any foreign instrument or object manipulated by another person for the purpose of arousing or gratifying the sexual desire of either party. Any penetration, however slight, is sufficient.

Id.

87. Ky. ReV. Stat. ANN. $§ 510.100$ (Michie 1974). 
(2) The penetration, however slight, of the vagina or anus of an animal or a person by any body member of a person of the same sex or an animal.

(b) Sodomy is a Class A misdemeanor. ${ }^{88}$

Finally, in 1989, Tennessee criminalized homosexual practices in its pointedly named Homosexual Practices Act found in the Tennessee Code at Section 39-13-510. ${ }^{89}$ The Act made it a Class C misdemeanor for a person to engage in consensual penetration, as defined by Section 39-13-501(7), with a person of the same sex..$^{90}$ The statute section in question defined sexual penetration as:

[S] exual intercourse, cunnilingus, fellatio, anal intercourse, or any other intrusion, however slight, of any part of a person's body or of any object into the genital or anal openings of the victim's, the defendant's or any other person's body, but emission of semen is not required. ${ }^{91}$

The common thread among all of these statutes is, of course, not just the specific prohibition of sodomy, as might have been common in the earlier half of the century, but sodomy as practiced between two persons of the same sex. ${ }^{92}$

\section{A Brief Overview of General Bias Against Homosexuality in the United States: Its Presence in the Courts and in the Population}

Between the time of the United States' independence and 1830, all thirteen of the original states adopted laws making sodomy a serious offense. ${ }^{93}$ After 1900, sodomy, which had traditionally been considered "a crime only men could commit," began to be prosecuted as a crime when committed by women as well as men. ${ }^{94}$ After World War I there was a distinct shift in the understanding of sodomy explicitly associating its performance with homosexuality. ${ }^{95}$ Additionally, both sodomy and homosexuality began to be

88. ARK. CODE ANN. § 5-14-122 (Michie 1977).

89. TENN. CODE ANN. § 39-13-510 (1989).

90. Id.

91. TENN. CODE ANN. § 39-13-501(7) (1989).

92. MONT. CODE ANN. § 45-5-505(1) (1973) defines "deviant sexual conduct" as "sexual contact or sexual intercourse between two persons of the same sex . . ." KY. REV. STAT. $\S$ 510.100 (Michie 1974) prohibits "deviate sexual intercourse with another person of the same sex." ARK. CODE ANN. § 5-14-122 (Michie 1977) prohibits "(1) penetration ... by the penis of a person of the same sex ... (2) penetration . . by the penis of a person of the same sex by any body member of a person of the same sex." TENN. CODE ANN. § 39-13-510 (1989) was entitled the Homosexual Practices Act.

93. Eskridge, supra note 56, at 645 .

94. Id. at 655 .

95. Id. at 659. 
associated with child molestation and "sexual psychopathy." The 1930s saw a "boom" in the arrests of homosexuals for public activities such as "kissing, groping, fondling and even hand holding in public or semipublic places.",97

Sodomy law enforcement became even more prevalent with the advent of the concept of homosexual men as "'sexual psychopath[s]' - the aggressive male who could not control his impulses and threatened children." 98 In response to this new vision of the homosexual male, many states instituted "sexual psychopath" laws permitting states to "incarcerate offenders for indeterminate periods of time." 99 These laws likely did indeed punish some "sexual psychopaths," but also incarcerated homosexual men indulging in consensual homosexual activities with other adult men. ${ }^{100}$

During the McCarthy Era (approximately 1947-1957) there were "unprecedented numbers of arrests for consensual oral sex between adults, because local vice squads invested substantial resources in detection of private and semipublic activities." ${ }^{101}$ In 1949, New York City police arrested 112 men for committing the crime of sodomy and 931 individuals for violating disorderly conduct laws governing "degenerate" acts. ${ }^{102}$

The social arguments against the homosexual community are legion. Some of the most common arguments are: "homosexuality is unnatural;" it "attacks the family;" the "Bible condemns homosexuality;" and "homosexuals recruit young people." 103 Reflections of these arguments can be seen in public opinion polls taken over the last thirty years. For example, in 1973, between 35 and $45 \%$ of the population expressed a distinct bias against homosexuals, including 35\% that believed homosexuals should not be "allowed to speak." 104 A telephone survey of a random sampling of U.S. adults revealed that $64 \%$ of those polled believed homosexuality to be "just plain wrong" and $50 \%$ expressed that "male homosexuals are disgusting." 105

96. Id.

97. Id. at 660 .

98. Id.

99. Id.

100. Id.

101. Id. at 661 .

102. Id. at 660 .

103. ReligiousTolerance.org, About Homophobia: Anti-gay laws, studies of homophobia;[sic] public opinion... [sic], at http://www.religioustolerance.org/hom_fuel2.htm (n.d.) (last visited Oct. 21, 2004) [hereinafter About Homophobia].

104. National Opinion Research Center Data, cited in Gregory Hereck, Sexual Prejudice, Sexual Orientation: Science, Education, and Policy, at http://psychology.ucdavis.edu/

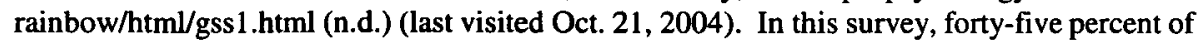
those polled believed that homosexuals should not be allowed to teach in a college or university and forty-five percent believed that books about homosexuality should be removed from libraries. Id.

105. About Homophobia, supra note 103. Unfortunately, this poll does not tell when it was taken. Other information available at this website indicates that it may have been taken in 1994 . See id. 
The homophobic feelings in the United States are reflected in every aspect of life in the United States. For example, in 1993, 85\% of teachers opposed integrating gay, lesbian and bisexual themes into their curricula; and in San Francisco, California, in 1994 , a poll revealed that " $18 \%$ would fire, $27 \%$ would refuse to hire, and $26 \%$ would refuse to promote a person they perceived to be lesbian, gay, or bisexual." 106

States continue to perpetuate discrimination against gay and lesbian individuals. A gay columnist noted in her online column that, in Florida, "[y]ou can do 60 days in . . . jail and be fined $\$ 500$ for breaking the legal prohibition on cunnilingus, fellatio or anal coitus, pardon my Latin." 107

Finally, the FBI reported in its annual statistics on hate crimes that, in the year $2002,16.6 \%(1,244)$ of the victims were targeted "because of their actual or perceived sexual orientation." 108 "Sexual orientation represents the third largest hate-motivation tracked by the FBI and [homosexual] victims represent the third largest group of victims ....,"109

Despite these statistics, bias against the homosexual community is actually decreasing in the United States. While $16.6 \%$ of hate-crime victims in the year 2002 were members of the homosexual community or perceived to be members of the homosexual community, this is an $11 \%$ decrease from the year $2001 .^{110}$ In contrast to the statistics of the 1973 poll mentioned above, in the year 2000,70 to $90 \%$ of the U.S. population had more positive views of homosexuality. ${ }^{111}$

Perhaps most encouragingly, even the definition of homophobia in the United States is changing. ${ }^{112}$ When heterosexual psychologist George Weinberg coined the term "homophobia" in the late 1960s, it was used "to label heterosexuals' dread of being in close quarters with homosexuals as well as homosexuals' self loathing." 113 In 1992, the American Heritage Dictionary

106. National Organization for Women, Come Out Against Homophobia! Did You Know?, at http://www.now.org/issue/lgbi/stats.html (n.d.) (last visited Oct. 21, 2004).

107. Sally Sheklow, Funny Old Broads, at http:/www.outsmartmagazine.com/issue/i0603/o-2-OutLoud.php (n.d.) (on file with the author).

108. Media Release, New York City Gay and Lesbian Anti-Violence Project, FBI Releases Annual Statistics on Hate Crimes Report's Deficiencies Underscore Continuing Need for Improved Federal Hate Crimes Tracking, (Oct. 28, 2003), http:/www.avp.org/publications/ media/2003-10-28\%20NCAVP\%20FBI\%20UR.htm (last visited Oct. 21, 2004).

109. Id.

110. Id.

111. National Opinion Research Data, supra note 104 . The poll showed that $90 \%$ of those polled now believe that homosexuals have a "right to speak" and 70\% believed that books about homosexuality should not be removed from libraries. Id.

112. Gregory Hereck, Sexual Prejudice, Sexual Orientation: Science, Education, and Policy, Definitions: Homophobia, Heterosexism, and Sexual Prejudice, athttp://psychology. ucdavis.edu/rainbow/html/prej_defn.html (n.d.) (last visited Oct. 21, 2004).

113. Id. 
defined homophobia as "an aversion to gay or homosexual people or their lifestyle or culture" and some definitions of homophobia even define it as an "irrational fear of homosexuality." 114

\section{E. A River of Change: Overturning State Statutes Criminalizing Homosexual Activity}

The States reflected the population's changing attitude toward homosexuality when they began overturning the statutes criminalizing homosexual activity. The first state to overturn its statute was Kentucky in 1992, followed by Tennessee in 1996, Montana in 1997, and Arkansas in 2002. This culminated in the Lawrence $v$. Texas decision in June, 2003, which not only invalidated the statute in Texas, but, as a case brought in federal court, overturned the precedent set in Bowers v. Hardwick in 1986.

In Commonwealth of Kentucky $v$. Wasson, the court ruled that the statute criminalizing homosexual activity in Kentucky was in violation of the state's constitutionally granted rights to privacy. ${ }^{115}$ The defendant had been arrested and charged after he allegedly solicited an undercover policeman to engage in deviate sexual intercourse in violation of Section 506.030. ${ }^{116}$ The activity would have occurred between consenting adults and with no offer of financial gain for participating in the activity. ${ }^{117}$ Wasson moved to dismiss the charges on the grounds that a statute, which criminalizes sexual behavior between consenting adults even if the act takes place in the privacy of a home, violates the Kentucky Constitution as "(1) an invasion of a constitutionally protected right of privacy; and (2) invidious discrimination in violation of constitutionally protected rights to equal treatment."118

The district court held that the statute violated Wasson's right to privacy and dismissed the charge. ${ }^{119}$ The appellate court affirmed and added that the statute "infringed upon equal protection guarantees found in the Kentucky Constitution." 20 The Kentucky Supreme Court recognized that the decision had been made by the lower courts solely based upon state constitutional issues and, therefore, confined its decision to the same. ${ }^{121}$

The Commonwealth's position was based purely upon the argument that homosexual activity is "immoral," arguing that "the majority ... has the right to criminalize sexual activity it deems immoral." 22 The Commonwealth went on

114. Id.

115. Ky. Stat. ANN. $\$ 510.100$ (Michie 1974). This statute prohibits "deviate sexual intercourse with another person of the same sex." Id.

116. Commonwealth of Kentucky v. Wasson, 842 S.W.2d 487, 488 (Ky. 1992).

117. Id. at 489.

118. Id. at 488 .

119. Id.

120. Id. at 489.

121. Id.

122. Id. at 490 . 
to say that the State may criminalize "immoral" behavior that is not harmful in and of itself "where there is a Biblical and historical tradition supporting it." 123

The Court reminded the Commonwealth that it is the job of the court to interpret the state constitution separately from the federal constitution and not to "march in lock step with the United States Supreme Court."124 The Court looked to the State's Bill of Rights and specifically cited Section 1, granting the citizens of Kentucky " $[t]$ he right of enjoying and defending their lives and liberties" and " $[t]$ he right of seeking and pursuing their safety and happiness." 125 The court looked also to Section 2 of the State's Bill of Rights which states "[a]bsolute and arbitrary power over the lives, liberty and property of freemen exists nowhere in a republic, not even in the largest majority."

The court looked to Commonwealth v. Campbell and concluded that the Kentucky Bill of Rights defined a right to privacy. ${ }^{127}$ The Court pointed out that the theory of the moral majority had changed on previous occasions. It looked to Loving $v$. Virginia as an example of such an evolution. ${ }^{28}$ The court further noted that two states had previously held such statutes unconstitutional for similar reasons. ${ }^{129}$ Therefore, this court, in making the decision that the statute unconstitutionally restricts the state's citizens' right to privacy "rather than being the leading edge of change, [was] but a part of the moving stream." 130

The State of Tennessee stepped into that moving stream in 1996 when its statute prohibiting sodomy between consenting adults of the same sex was found unconstitutional in Campbell $v$. Sundquist. ${ }^{131}$ The Plaintiffs in this matter filed a petition for declaratory and injunctive relief alleging that the statute, the Homosexual Practices Act violated their right to privacy and their right to equal protection under Article 1 of the state constitution. ${ }^{132}$ Article 1, Section 8 , of the Tennessee Constitution states:

123. Id.

124. Id. at 492.

125. Id. at 494 .

126. Id.

127. Id. at 495 (quoting Campbell v. Commonwealth 117 S.W. 383, 386 (Ky. 1909)). "Let a man therefore be everso abandoned in his principles,... provided he keeps his wickedness to himself, and does not offend against the rules of public decency, he is out of the reach of human laws." Id.

128. Id. at 497 (quoting Loving v. Virginia, 388 U.S. 1, 87 (1967)). "[The Court] recognized that a contemporary, enlightened interpretation of the liberty interest involved in the sexual act made its punishment constitutionally impermissible." Id. Loving removed the criminalization of miscegenation (marriage or intercourse between the races), which, the court points out here, had "ancient roots" similar to those "ancient roots" referred to in Bowers. Id.

129. Id. at 498 (citing People v. Onofre, 51 N.Y.2d 947 (N.Y. 1980) and Commonwealth v. Bonadio, 415 A.2d 47 (Pa. 1980)).

130. Id. .

131. Campbell v. Sundquist, 926 S.W.2d 250 (Tenn. App. 1996).

132. Id. at 253. 
No man to be disturbed but by law. That no man shall be taken or imprisoned, or disseized of his freehold, liberties or privileges, or outlawed, or exiled, or in any manner destroyed or deprived of his life, liberty or property, but by the judgment of his peers or the law of the land.

The Plaintiffs asserted that since this provision has always been "substantially identical" with the Fifth and Fourteenth Amendments of the U.S. Constitution, the right to privacy in Tennessee should only protect those rights protected by the federal right to privacy - marriage, procreation, and child rearing. ${ }^{133}$

The court reminded the parties it was not bound by Bowers. ${ }^{134}$ The court further stated that while the drafters of Tennessee's constitution could not have envisioned every scenario that would arise over the centuries, it was certain that they "foresaw the need to protect individuals from unwarranted governmental intrusion ... involving intimate questions of personal . . concern."

The court looked briefly at the State's argument for a compelling state interest in prohibiting homosexual sodomy. The State alleged five state interests that were advanced by the Homosexual Practices Act, including that (1)the Act was intended to discourage activities that did not lead to procreation; (2) the choice of a "socially stigmatized" lifestyle led to drug and alcohol abuse and suicide; (3) the Act discouraged homosexual relationships because they are "short lived, shallow and initiated for the purpose of sexual gratification;" (4) "the Act prevents the spread of infectious disease;" and finally, (5) the Act promoted the "moral values" of the citizens of Tennessee. ${ }^{136}$

The court quickly dispensed with the State's allegedly "compelling interests" by reminding the State that citizens had the right to procreate or not, at their discretion. ${ }^{137}$ The court found that the "State's attempt to rescue homosexuals from a socially unpopular lifestyle does not provide a compelling reason . . . for infringement of the fundamental right of adults to engage in private, noncommercial, consensual sex." 138 The Court found no evidence that the Homosexual Practices Act discourages drug and alcohol abuse and suicide and no evidence that homosexual relationships are "short lived" and "weaken the 'fabric' of the community." 139 The court held that the statute was "actually counterproductive to public health goals" since it caused people to fear treatment for infectious disease. ${ }^{140}$ Finally, the court found that:

133. Id. at 259.

134. Id.

135. Id. at 260 (quoting Davis v. Davis, 842 S.W.2d 588, 600 (Tenn. 1992)).

136. Id. at 262.

137. Id. at 263 .

138. Id.

139. Id.

140. Id. at 264. 
Even if we assume that the Homosexual Practices Act represents a moral choice of the people of this State, we are unconvinced that the advancement of this moral choice is so compelling as to justify the regulation of private noncommercial, sexual choices between consenting adults simply because those adults happen to be of the same gender. ${ }^{141}$

In short, the Tennessee Court of Appeals entered the stream of change by holding:

[A]n adult's right to engage in consensual and noncommercial sexual activities in the privacy of that adult's home is a matter of intimate, personal concern which is at the heart of Tennessee's protection of the right to privacy and that this right should not be diminished or afforded less constitutional protection when the adults engaging in that private activity are of the same gender. ${ }^{142}$

Montana instituted its ban on sodomy between members of the same sex in $1973 .{ }^{143}$ In 1997, in Gryczan v. State, Montana entered what can no longer be described as a stream, but rather a river of states decriminalizing homosexual activity. ${ }^{144}$ Citizens of the State of Montana filed a declaratory judgment action challenging the constitutionality of the statute under the Montana Constitution and the Fourteenth Amendment to the U.S. Constitution. ${ }^{145}$

The Plaintiffs contended that the statute violated Article II, Section 10, of the Montana Constitution, which provides that "the right of individual privacy is essential to the well being of a free society and shall not be infringed without the showing of a compelling state interest." 146 As in other cases of this nature, the State contended that the U.S. Supreme Court in Bowers had already resolved the issue, and that there was no right to privacy in existence for homosexual activity. ${ }^{147}$

The Montana Supreme Court, like the courts in both Kentucky and Tennessee, reminded the State that regardless of whether or not Bowers was decided correctly, the Montana courts have "long held that Montana's Constitution affords citizens broader protection of their right to privacy than does the federal constitution." 148 The Montana Supreme Court agreed with the

141. Id. at 265 .

142. Id. at 262 .

143. MonT. CodE ANN. $\$ 45-5-505$ (1973).

144. Gryczan v. State, 942 P.2d 112 (Mont. 1997).

145. Id. at 115.

146. Id. at 121.

147. Id.

148. Id. 
district court's finding in the case that "while many Montanans do not approve of homosexual activity, that is not to say that society is unwilling to recognize as reasonable an expectation of privacy as to consensual, adult, private samegender sexual conduct."149

Regarding the State's allegedly "compelling interest" in protecting the public morality of the State of Montana, the court looked to Campbell $v$. Sundquist in which the Tennessee Court of Appeals stated:

With respect to regulation of morals, the police power should properly be exercised to protect each individual's right to be free from interference in defining and pursuing his own morality but not to enforce a majority morality on persons whose conduct does not harm others .... Indeed, what is considered to be "moral" changes with the times and is dependent upon societal background. Spiritual leadership, not the government, has the responsibility for striving to improve the morality of individuals. ${ }^{150}$

The Montana Court held that the State had no compelling interest for "such an intrusion" into the private lives of its citizens. ${ }^{151}$

The Montana court, in line with previous decisions in Kentucky and Tennessee, found that the Montana Constitution created a right to privacy which did not allow the State's intrusion into the private sexual lives of its homosexual citizens and stated that "there are certain rights so fundamental that they will not be denied to a minority no matter how despised by society. In Montana, the right of privacy is such a right." 152

In 2002, the State of Arkansas, with a statute criminalizing homosexual activity on its books since 1977 , waded into the river of change with its landmark case Jegley v. Picado. ${ }^{153}$ Citizens of Arkansas brought a suit for declaratory judgment and an injunction against the enforcement of Arkansas Code Section 5-14-122, which criminalized sodomy between individuals of the same sex. ${ }^{154}$ Plaintiffs alleged that they were harmed as the statute criminalized their intimate conduct and violated their privacy. ${ }^{155}$ The citizens contended that the Arkansas Constitution provided an inherent right to privacy, the existence of which made the statute in question unenforceable. ${ }^{156}$ Again, the State argued that the U.S. Constitution did not include a fundamental right to commit

149. Id. at 122.

150. Id. at 125 (quoting Campbell v. Sundquist, 926 S.W.2d 250, 265-66 (Tenn. Ct. App. 1996) (quoting Commonwealth v. Bonadio, $490 \mathrm{~Pa}$. 91, 415 A.2d 47, 50 (Pa. 1980))).

151. Id. at 126.

152. Id. at 125 .

153. Jegley v. Picado, 80 S.W.3d 332 (Ark. 2002).

154. Id. at 334.

155. Id. at 335.

156. Id. at 344 . 
homosexual sodomy and that the need to protect the morality of the state provided a rational basis for the sodomy statute in question. ${ }^{157}$

The Arkansas Court acknowledged that there was no federally protected right to commit homosexual sodomy, but, as other states had before it, determined that it was possible that the Arkansas Constitution contained a right to privacy "more protective than the federal right." 158 The court noted the similarity between the Arkansas and Kentucky Constitutions regarding the right to privacy. ${ }^{159}$

In examining the state constitution, the court looked first to Article 2, Section 29 , which provides that the rights granted by the constitution "must not be construed ... to deny . . . other rights retained by the people."160 Having made this determination, the court advanced to an exploration of Article 2, Section 2, which provided in pertinent part that "all men are created equally free and independent, and have certain inherent and inalienable rights, amongst which are those of enjoying and defending life and liberty; ... and of pursuing their own happiness." ${ }^{161}$ The court also looked to Article 2, Section 15, of the Arkansas Constitution, which guaranteed citizens the right "to be secure in their persons, houses, papers and effects against unreasonable searches and seizures."

The court further noted that Article 2, Section 18, of the Arkansas Constitution required that privileges or immunities not be granted to any citizen or class of citizens "which upon the same terms shall not equally belong to all citizens." ${ }^{\text {"63 }}$ After considering the constitution along with other statutes, rules, and case law, the Arkansas Supreme Court concluded that the State had a "rich and compelling tradition of protecting individual privacy and that a fundamental right to privacy is implicit in the Arkansas Constitution."164

The court also considered whether the State's interest in protecting public morality was sufficiently compelling to allow the statute to stand and concluded that it was not. ${ }^{165}$ The court ruled that the State had not shown that the legislation bore a "real or substantial relationship to the protection of public health, safety and welfare" to justify "the prohibition of consensual, private intimate behavior between persons of the same sex."166

157. Id. at 335 ,

158. Id. at 346.

159. Id. (citing Commonwealth v. Wasson, 842 S.W.2d 487 (Ky. 1992)).

160. Id. at 346-47.

161. Id. at 347.

162. Id.

163. Id.

164. Id. at 349-50.

165. Id. at 353 .

166. Id. 
In conclusion, the Arkansas Court held that:

The fundamental right to privacy implicit in our law protects all private, consensual, noncommercial acts of sexual intimacy between adults. Because [the statute] burdens certain sexual conduct between members of the same sex, we find that it infringes upon the fundamental right to privacy guaranteed to the citizens of Arkansas. ${ }^{167}$

F. The Crest of the River: Overturning Bowers in the Lawrence Decision.

While the states of the Union were chipping away at the criminalization of homosexual activity, the U.S. Supreme Court's decision in Bowers remained in place. Bowers v. Hardwick, complete with its commentary identifying homosexual activity as "an offense of 'deeper malignity' than rape," stood in the river like a steadfast boulder while change flowed around it. ${ }^{168}$ However, on June 26, 2003, the boulder of Bowers crumbled, and the federal courts joined the river with the Supreme Court's decision in Lawrence v. Texas. ${ }^{169}$

In Lawrence, Houston, Texas, police officers responded to a reported weapons disturbance at the private residence of petitioner, John Lawrence, where the officers observed Lawrence and another man engaged in a prohibited sexual act. ${ }^{170}$ The violation occurred under Texas Penal Code Section 21.06(a), which makes it a criminal offense to "[engage] in deviate sexual intercourse with another individual of the same sex."171 Lawrence and his partner, Tyron Garner, were arrested, held overnight in custody, and charged and convicted. ${ }^{172}$

Lawrence and Garner alleged a violation of the Equal Protection Clause of the Fourteenth Amendment of the U.S. Constitution, and a similar provision in the Texas Constitution. ${ }^{173}$ Both contentions were rejected and the gentlemen were fined and assessed court costs. ${ }^{174}$ The petitioners appealed and, in a divided en banc opinion, the court of appeals affirmed the convictions, citing Bowers as controlling. ${ }^{175}$

167. Id. at 350.

168. Bowers v. Hardwick, 478 U.S. 186, 197 (1986) (Burger, J., concurring) (citing 4 W. Blackstone Commentaries 215).

169. Lawrence v. Texas, 539 U.S. 558 (2003).

170. Id. at 563.

171. The statute defined "[d]eviate sexual intercourse" as follows:

(A) any contact between any part of the genitals of one person and the mouth or anus of another person; or

(B) the penetration of the genitals or the anus of another person with an object.

Tex. Penal Code $\$ 21.06$ (a) (Vernon 2003).

172. Lawrence, 538 U.S. at 563.

173. Id.

174. Id.

175. Id. 
The Supreme Court granted certiorari to consider whether the statute violated the Equal Protection Clause, the right to privacy protected in the Due Process Clause, and, finally, whether it was time to overturn Bowers. ${ }^{176}$

The Court disagreed with the way the Bowers Court had framed the issue. The Bowers Court identified the issue as being whether the U.S. Constitution granted homosexuals a fundamental right to commit sodomy and, therefore, invalidated the laws of many states making such conduct illegal as they had for "a very long time." 177 The Lawrence Court stated that the Bowers Court failed to "appreciate the extent of the liberty at stake" and that to say the issue in Bowers was merely the right to engage in particular sexual conduct "demean[ed] the claim the individual put forward, just as it would demean a married couple were it to be said marriage is simply about the right to have sexual intercourse."

The Lawrence Court went further and said that the statute touches upon the "most private human conduct, sexual behavior, and in the most private of places, the home. The statutes do seek to control a personal relationship that ... is within the liberty of persons to choose without being punished as criminals." 179 This should, the Court ruled, "counsel against attempts by the State, or a court, to define the meaning of the relationship ... absent injury to a person or abuse of an institution the law protects." 180 "The liberty protected by the Constitution allows homosexual persons the right to make this choice."181

The Lawrence Court then addressed the contention by the Bowers Court that the proscription against homosexual conduct has "ancient roots." 182 The Court essentially held that the historical perspective adopted in Bowers was incorrect and that there "is no longstanding history in this country of laws directed at homosexual conduct as a distinct matter."183 Rather, early proscriptions against sodomy were directed against both same-sex and heterosexual couples in an attempt to limit non-procreative sexual activities in a more general sense. ${ }^{184}$ The Court further noted that it was not possible for legal proscriptions against sodomy as it applies to homosexuals to have "ancient roots" as the "concept of the homosexual as a distinct category of person did not emerge until the late $19^{\text {th }}$ century." 185 In short, the Court concluded that the historical premise relied upon in Bowers was "not without doubt and, at the very least, are overstated."186

176. Id. at 574 .

177. Bowers, 478 U.S. at 190.

178. Lawrence, 539 U.S. at 567.

179. Id.

180. Id.

181. Id.

182. Bowers, 478 U.S. at 192.

183. Lawrence, 539 U.S. at 568.

184. Id.

185. Id.

186. Id. at 571 . 
Lawrence also addressed the Bowers argument that homosexuality had historically been condemned not only in the legal arena, but also by "JudeoChristian moral and ethical standards." 187 The Court acknowledged the importance that such ethics and ideals hold in the lives of many, but determined that the history of this "moral condemnation" is open to a variety of interpretations and that, in any event, "the laws and traditions in the past half century are of the most relevance here." before the Court was "whether the majority may use the power of the State to enforce these views on the whole society through operation of the criminal law. 'Our obligation is to define the liberty of all, not to mandate our own moral code.",189

Lawrence looked at Bowers as an anomaly during an "emerging awareness that liberty gives substantial protection to adult persons in deciding how to conduct their private lives in matters pertaining to sex." 190 The Court was surprised that the Bowers Court did not recognize that emerging trend, as it "should have been apparent."191

In making its decision, the Court looked to two cases decided after Bowers: Planned Parenthood of Southeastern Pa. v. Casey ${ }^{192}$ and Romer v. Evans. ${ }^{193}$ The Court reiterated the Casey decision granting constitutional protection to personal decisions, noting: ${ }^{194}$

These matters involving the most intimate and personal choices a person may make in a lifetime, choices central to personal dignity and autonomy are central to the liberty protected by the Fourteenth Amendment. At the heart of liberty is the right to define one's own concept of existence, of meaning, of the universe, and of the mystery of human life. Beliefs about these matters could not define the attributes of

187. Id.

188. Id. at 571-72.

189. Id. at 571 (quoting Planned Parenthood of Southeastern Pa. v. Casey, 505 U.S. 833, 850 (1992)).

190. Id. at 572 .

191. Id.

192. Id. at 571 (citing Planned Parenthood of Southeastern Pa. v. Casey, 505 U.S. 833 (1992)). "[C]onstitutional protection [of] personal decisions relating to marriage, procreation, contraception, family relationships, child rearing, and education." Id.

193. Lawrence, 539 U.S. at 574 (citing Romer v. Evans, 517 U.S. 620 (1996)). In Romer, the "Court struck down class-based legislation directed at homosexuals as a violation of the Equal Protection Clause." Id. The legislation named homosexuals, lesbians and bisexuals as a class and "deprived them of protection under state antidiscrimination laws." Id. (quoting Romer, 517 U.S. at 624).

194. Id. 
personhood were they formed under compulsion of the State. ${ }^{195}$

In light of the Casey decision, the Lawrence Court determined that "[p]ersons in a homosexual relationship may seek autonomy for these purposes, just as heterosexual persons do." 196

In considering the national trend in the legal system toward the decriminalization of homosexual activity, the Court also turned to cases discussed earlier in this Note, where states found statutes criminalizing homosexual activity to violate their state constitutions. ${ }^{197}$ Moreover, the Court found that there was no state interest sufficient to "justify [the statute's] intrusion into the personal and private life of the individual," nor was there sufficient individual or societal reliance on Bowers that "could counsel against overturning its holding." 198

The Court concluded its decision by stating:

[This] case . . . involve[s] two adults who, with full and mutual consent from each other, engaged in sexual practices common to a homosexual lifestyle. The petitioners are entitled to respect for their private lives. The State cannot demean their existence or control their destiny by making their private sexual conduct a crime. Their right to liberty under the Due Process Clause gives them the full right to engage in their conduct without intervention of the government.

In short, the Court determined that "Bowers was not correct when it was decided, and it is not correct today. It ought not to remain binding precedent. Bowers v. Hardwick should be and now is overruled." 200

In looking at a recent legal history defining the right to privacy in relation to sexual matters, it is clear that the trend in the past fifty years has been to broaden the penumbra of rights included in the right to privacy. ${ }^{201}$ One of the

195. Id. (quoting Planned Parenthood of Southeastern Pa., 505 U.S. at 851).

196. Id.

197. Id. (citing Jegley v. Picado, 80 S.W.3d 332 (Ark. 2002); Powell v. State, 510 S.E.2d 18 (Ga. 1998), Gryczan v. State, 942 P.2d. 112 (Mont. 1997); Campbell v. Sundquist 926 S.W.2d 250 (Tenn. Ct. App. 1996); and Commonwealth v. Wasson, 842 S.W.2d 487 (Ky. 1992)). (These cases struck statutes criminalizing homosexual activity in, respectively, Arkansas, Georgia, Montana, Tennessee and Kentucky.)

198. Id. at 578 .

199. Id.

200. Id.

201. See generally Griswold v. Connecticut, 381 U.S. 479 (1965) (holding that married couples had a constitutional right to use contraceptive devices); Eisenstadt v. Baird, 405 U.S. 438 (1972) (holding that unmarried individuals had a constitutional right to use contraceptive devices); Roe v. Wade, 410 U.S. 113 (1973) (holding that a woman had a constitutional right to 
earlier decisions in this area, Griswold, prohibited the State from interfering with the reproductive decisions of married, heterosexual couples. ${ }^{202}$ This was followed by Eisenstadt which granted unmarried individuals the right to make decisions about birth control without interference from the State. ${ }^{203}$ Roe $v$. Wade enforced a sphere of privacy encircling reproductive choices when it prohibited the State from interfering in a woman's right to choose to have an abortion. ${ }^{204}$ Carey v. Population Services made it clear that everyone, regardless of marital status or age, had the right to prevent conception through the use of contraceptives. ${ }^{205}$ However, as the heterosexual population was enjoying an expansion of its rights to keep sexual matters private, the homosexual community was experiencing the opposite as states instituted legislation banning homosexuals from performing acts of sexual intimacy solely because those acts took place between people of the same sex. ${ }^{206}$

Bowers solidified the line between the right to privacy in the heterosexual community and the right to privacy in the homosexual community, making it clear that the lesbian and gay community was still considered a separate community with different, and fewer, rights to privacy in their intimate lives. However, the revolution in the right to privacy did arrive at the homosexual community's doorstep as states began failing to actively enforce statutes prohibiting homosexual activity, and then striking the statutes as violating the state, if not the federal, constitution. ${ }^{207}$ This culminated in the Lawrence decision, granting homosexual citizens the right, for the first time, to have matters of sexual intimacy kept private. ${ }^{208}$ For the first time, the gay and lesbian community could engage in sexual intimacy in the privacy of their own homes, and expect it to remain private and free from State interference. ${ }^{209}$

\section{THE TREATMENT OF SODOMY AND THE HOMOSEXUAL COMMUNITY IN NICARAGUA}

In order to look at the treatment of sodomy in Nicaragua, it is important to understand the differences in the development of the Nicaraguan Constitution and Nicaraguan law as compared to the United States. Nicaragua has a unique combination of circumstances in that modern Nicaragua was without a constitution from the time of the overthrow of the Somoza dictatorship in 1974 until the new legislators took their seats in the National Assembly in $1985^{210}$

terminate a pregnancy through abortion); Carey v. Population Services Int'1, Inc., 431 U.S. 678 (1977) (holding that minors had a constitutional right to access contraceptive devices).

202. 381 U.S. 479 (1965).

203. 405 U.S. 438 (1972).

204. 410 U.S. 113 (1973).

205. 431 U.S. 678 (1977).

206. Bowers v. Hardwick, 478 U.S. 186 (1986).

207. See supra Part II.E.

208. Lawrence v. Texas, 539 U.S. 558, 578 (2003).

209. Id.

210. Martha I. Morgan, Founding Mothers: Women's Voices and Stories in the 1987 Nicaraguan Constitution, 70 B.U. L. REV. 1, 20 (1990). The Sandinista National Liberation 
and promulgated a Constitution in $1987 .^{211}$ Residents of the United States often forget, or simply do not know, that "more than half the world's written national constitutions have been drafted since 1974."212 The 1987 Constitution was the ninth constitution in Nicaraguan history. ${ }^{213}$

In contrast to the new constitution in Nicaragua is the Nicaraguan Penal Code. In 1974, the Penal Code was little different from the code originally promulgated in 1879 , and strongly reflected the influence of the Napoleonic Code. ${ }^{24}$ For example, the 1974 Code still reflected the traditions of the Napoleonic Code by considering married women as people without rights under the law, along with minors, criminals, and the mentally handicapped. ${ }^{215}$

\section{A. Constraining Traditions in Nicaragua: Machismo, the Roman Catholic} Church, and Perceptions of the Court System.

Nicaragua is also constrained by three other long-lasting traditions: machismo, the influence of the Roman Catholic Church, and perceptions of the Nicaraguan court system. Nicaragua has a long-standing tradition of machismo. ${ }^{216}$ The late Carlos Nunez, former President of the Nicaraguan National Assembly, described the concept of machismo as follows:

To me, machismo is a particular form of manifestation of the oppression by the male of the female that not only carries with it discriminatory attitudes, but since the disappearance of matriarchy and the imposition of patriarchy, has meant reducing the female to the condition of object, with the male acting as head of the family, and thus demanding, ordering, and imposing, without taking into account what I would call the exercise of democracy inside the house and outside of it. ${ }^{217}$

This constant presence of machismo in Nicaraguan society might seem to affect only women, but it has a direct effect upon the homosexual community as well. $^{218}$ While the terms "homosexual" and "gay" are being used more frequently in Nicaraguan society, the derogatory term, cochon, is still often used. ${ }^{219}$ The term refers to the "passive" partner in a male homosexual

Front (FSLN) defeated the Somoza regime in a military battle and forced its leaders and many followers into exile. U. S. Dep't of State, Bureau of Democracy, Human Rights and Labor, Nicaragua - Profile of Asylum Claims and Country Conditions (Mar. 1997).

211. Id. at 26.

212. Morgan, supra note 210 , at 3.

213. Nicaragua - Constitutional Background, AllRefer.com Reference, http://reference. allrefer.com/country-guide-study/nicaragua/nicaragua87.htm (n.d.) (last visited Oct. 21, 2000))

214. Morgan, supra note 2, at 449.

215. Id.

216. Id. at 440 .

217. Id. at n.3.

218. Id. at 460 .

219. Id. 
relationship. ${ }^{220}$ In Nicaragua, as in many Latin American countries, the "passive" male partner is the person most frequently stigmatized while the "perpetrator's" actions are seen as consistent with the "norms of masculinity in a culture of machismo.",221

This culture of machismo has contributed to the homophobia that is still rampant in Nicaragua today. ${ }^{222}$ In 1992, Luis Sanchez Sancho, the acting President of the National Assembly, stated during an interview that he "would rather have a daughter who is a prostitute than a son who is a cochon."223

With homophobia so accepted among the highest government officials, it is perhaps not surprising that there are a limited number of Nicaraguans willing to discuss their sexual orientation. ${ }^{224}$ When writing an article about the Nicaraguan Constitution in 1995, Martha Morgan noted that "by late 1994, only about a dozen gay and lesbian individuals in Nicaragua were fully out of the closet and willing to speak publicly about their sexual orientation."225

The government continues to perpetuate a bias against homosexuals in Nicaragua. A gay citizen of Nicaragua, and a member of an LGBT ${ }^{226}$ organization, Puntos de Encuentro, notes that while such organizations are permitted to function, "the National Assembly has never approved a specific legal status that would allow [them] to exist as such." ${ }^{227}$ The same individual noted that the general situation for members of the gay community in Nicaragua is "very difficult, as a daily struggle to convince the family, friends and work or study colleagues that we are equal ...."228

In Nicaragua, the Roman Catholic Church continues to have a heavy influence in the lives and views of its citizens. ${ }^{229}$ The Roman Catholic Church was first established in Nicaragua in $1524 .{ }^{230}$ Roman Catholicism remained the official established faith in Nicaragua until 1939. ${ }^{231}$ "When Nicaraguans speak of 'the church' they mean the Roman Catholic Church."232

220. Id.

221. Id. at 469 .

222. Id.

223. Id. at n.96.

224. See id. at n.92.

225. Id. at n.92.

226. "LGBT" is a standard acronym, which stands for "lesbian, gay, bisexual and transsexual."

227. Politics, Survey regarding LGBTs in Costa Rica and Nicaragua, at http://www.dream water.com/women/theresles/politics.html (2002) (last visited Sept. 26, 2004) [hereinafter Survey].

228. Id.

229. Morgan, supra note 210, at 37 . Morgan describes Nicaragua as a "heavily Catholic" country. Id.

230. Project Nicaragua, Spirituality, at http://www.settlement.org/cp/english/nicaragua/ spirit.html (n.d.) (last visited Oct. 21, 2004) [hereinafter Spirituality].

231. Global Missions Fellowship, at http://www.gmfdallas.org/shorttermissions/calendarb ycountry.asp?Country=Nicaragua (on file with author).

232. Id. 
Although the Nicaraguan constitutions since 1939 have included provisions for a secular state and have guaranteed freedom of religion, the Church continues to have a "special status" in Nicaraguan society. ${ }^{233}$ Indeed, the Roman Catholic Church took part in drafting the Constitution. ${ }^{234}$ "Its leadership, represented by the Nicaraguan Conference of Bishops, issued a pastoral letter following publication of the first constitutional draft in which it stressed its opposition to military conscription and family planning."235 Bishops of the Church continue to lend their authority to state occasions and "their pronouncements on national issues are closely followed."236 Representatives of the Church acknowledge its role in politics only in a "broad sense as [it] look[s] for the common well being of the nation." some religious leaders hold "important" offices in the Nicaraguan government. ${ }^{238}$ The influence of the Church continues to be so strong in Nicaragua that, some say it "constitutes (unofficially) another state power.",239

During the $1980 \mathrm{~s}$, the leaders of the Church were often opposed to governmental policies. ${ }^{240}$ In contrast, the 1990 s ushered in a time of closer ties between the Nicaraguan government and the Nicaraguan Roman Catholic Church. ${ }^{241}$ The present government has close ties to the Vatican and has given its support to the Church. ${ }^{242}$ As a result, the Church often plays a variety of roles in Nicaraguan society and government. ${ }^{243}$ Overall, "[g]overnments since

233. Id.

234. Andrew Reding, Nicaragua's New Constitution, 4 WORLD POL. J. 2 (1987), available at http://worldpolicy.org/globalrights/nicaragua/1987-spring-WPJ-Nicaragua.html (last visited Oct. 31, 2004).

235. Id.

236. Global Missions Fellowship, supra note 231.

237. Interview with His Excellency Miguel Obando Y Bravo, Cardinal of the Catholic Church in Nicaragua, at http://www.library.thinkquest.org/17749/1churchintsr.html (on file with author) [hereinafter Interview].

238. Spirituality, supra note 230.

239. Survey, supra note 227 . The individual quoted made this comment specifically about Nicaragua. Id.

240. Spirituality, supra note 230. The Roman Catholic Church was often opposed to the Sandinista government's social and economic policies. Id.

241. Id.

242. Id.

243. Id. For example, the Church was involved in negotiations when commandos held Nicaraguan officials hostage. Later, the Church was also involved in mediations with Sandanistan warriors. Interview, supra note 237. Additionally, "a large part of the education systems, in particular the private institutions that serve most upper-and middle-class students, is controlled by Roman Catholic bodies." Id. See also Global Missions Fellowship, supra note 231. "There are allegations that state funds have been used to support church-related activities that are purely religious in nature." U.S. Department of State, Bureau of Democracy, Human Rights and Labor, Nicaragua - International Religious Freedom Report 2002, at http://www.state.gov/g/drl/rls/irf/202/14052.htm (Oct. 7, 2002) (last visited Oct. 21, 2004). There have also been allegations from other religious bodies that they experience bureaucratic delay in obtaining exoneration from custom duties for donated goods intended for humanitarian aid. Id. Religious organizations not tied to the Catholic Church have suggested that the "Catholic Church received preferential treatment in this regard and in practice did not face the 
1990 have tended to uphold traditional Roman Catholic values."244

"[T] he current official position of most organized religions . . . remains unabashedly heterosexist [and] the historical and current official beliefs, as well as the routine practices, of the Roman Catholic Church continue to be stridently homophobic and sexphobic." "245 "[A]lthough Nicaragua is a secular state, there is still a strong influence of the Catholic Church, which continues imposing in [the Nicaraguan] culture the idea of sin if anyone chooses a non-heterosexual preference." 246 The Roman Catholic Church continues to be a "great influence on the current government and it is a major obstacle for the recognition of LGBT citizens's [sic] rights. Its position is to try to eliminate any formal expression of the reality that we [homosexuals] live in, work in and contribute to the development of Nicaragua."247 In response to protests against a new provision of the Nicaraguan Penal Code criminalizing sodomy between members of the same sex, the President of the National Assembly stated "[f]or Christians, which the immense majority of we Nicaraguans are, sodomy is contrary to natural law and Divine Law and its propagation in the society merits the biblical punishment that fell on the city of Sodom.",248

Given the continued hold of both the Roman Catholic Church and the culture of machismo in Nicaragua, the Nicaraguan attitude toward homosexuality and homosexual practices is not surprising. In contrast to the United States, which is reducing its legal bias against homosexual activity, Nicaragua is broadening its discrimination against homosexual activity.

The final stumbling block in Nicaraguan society is one that might seem rather odd to a citizen of the United States. Simply stated, the courts are not seen as effective agents of change in Nicaragua. ${ }^{249}$ Some of this attitude may relate simply to the nature of the courts in Nicaragua's civil law system. ${ }^{250}$ "[C]ivil law systems traditionally [limit] the role of the courts more sharply than the common law systems."251 A civil law system usually relies on written codes

same bureaucratic requirements applied to other religious and humanitarian organizations." Id. After these allegations were made, Catholic organizations reported that they had difficulties similar to non-Catholic organizations. Id. Although the government addressed the problem by publishing additional guidelines in 1999, "the issue remained controversial during the period covered by this report." Id.

244. Global Missions Fellowship, supra note 231. "For example, the government has made attempts to restrict women's roles in the workplace and to focus on their roles as housewives and mothers." Id.

245. Elizabeth M. Iglesias \& Francisco Valdes, Afterword: Religion, Gender, Sexuality, Race and Class in Coalitional Theory: A Critical and Self-Critical Analysis of Latcrit Social Justice Agendas, 19 Chicano-Latino L. REV. 503, 548 (1998).

246. Survey, supra note 227 . The individual quoted made this comment specifically about Nicaragua. $1 d$.

247. Id.

248. Morgan, supra note 2 , at 468 .

249. Id. at 481 .

250. Id. at 482 .

251. Id. 
or statutes "as sources of law to a much greater extent than do common-law systems." 252

The courts are allowed only to interpret and apply law, not change it and the laws they are charged with enforcing are often "antiquated codes." 253 In fact, Nicaragua has "changed its constitution more frequently than it has changed its codes." older procedural counterparts . . ., contain archaic provisions that flagrantly contradict the guarantees of the new constitution."235 Even more curious to individuals used to the methods of the United States, the Nicaraguan courts generally apply judicial decisions only to the case at hand, and there is "no binding precedential value even for lower courts." 256

Nicaragua is not the only Latin American country with such a problem. ${ }^{257}$ In Columbia, the citizens often refer to their judiciary branch as "Cindarella[sic]."258 However, these problems are noted to be particularly acute in Nicaragua. ${ }^{259}$ Rodrigo Reyes Portecarrero, former President of the Nicaraguan Supreme Court, summarized the problem succinctly:

It would not occur to anyone here to use the legal system as an instrument of power to change things. It would not occur to anyone. Here, they would think of taking to the streets, or of going on strike, or of making a scandal, or of making barricades, or of complaining to the National Assembly, but we Nicaraguans are not accustomed to using the mechanism of law as an instrument to obtain justice.... We don't believe in the law. It is a cultural problem of ours. ${ }^{260}$

\section{B. Broadening the Nicaraguan Penal Code and the Role of the Constitution}

The 1974 Penal Code addressed the issue of sodomy. Under Article 205, the Penal Code provided:

Concubinage between persons of the same sex or against nature constitutes sodomy and those who practice it in a manner that is scandalous or outraging modesty or public morality will suffer the penalty of one to three years in prison;

252. Morgan, supra note 210 , at 27.

253. Morgan, supra note 2, at 482.

254. Morgan, supra note 210 , at 27.

255. Id.

256. Morgan, supra note 2, at 482 .

257. Id.

258. Id. at 483.

259. Id.

260. Id. 
but if one of those who practices it, even in private, had over the other disciplinary or control, as superior, guard, teacher, boss, guardian or in whatever other form that implies influence or authority or moral direction, the penalty shall be for him, from two to four years, the same as when it is practiced with one less than 15 years old or with force or intimidation. ${ }^{261}$

When preparing the new constitution, the initial reform proposal simply deleted this provision as a response to "growing concern about the penal code's outmoded treatment of sodomy." "262 "However it soon became clear that the 1979 revolution had not changed society's negative attitudes towards the gay and lesbian community. ${ }^{263}$

Initially, perhaps no one noticed the deletion of the sodomy provision, but, eventually, the assembly committees did, indeed, notice the deletion. ${ }^{264}$ While it is still not known who proposed the new language of the sodomy law, by the time the reform bill reached the full assembly, not only had sodomy been revived as a crime, but the definition had been broadened to include "inducing, promoting and propagandizing." 265 The addition of this new language provoked such heated debate that a vote was taken twice, but ultimately the new language was preserved. ${ }^{266}$ The article, approved as Article 204 of the penal code, now states as follows:

He commits the crime of sodomy who induces, promotes, propagandizes or practices in a scandalous manner concubinage between two persons of the same sex. He will suffer the penalty one to three years in prison. When one of those who practices this, even in private, has over the other disciplinary power or control, as superior, guard, teacher, boss, guardian or in whatever manner that involves influence or authority or moral direction, the penalty for illegitimate seduction will apply to him as the only responsible party. ${ }^{267}$

The language of this article is ambiguous in some senses and extremely clear in others. ${ }^{268}$ The law clearly distinguishes between heterosexual and homosexuals in two ways. First, the change of language in this provision is

261. COD. PEN art. 205 (1974) (Nicar.).

262. Morgan, supra note 2, at 460.

263. Id.

264. Id.

265. Id. at 461 .

266. Id.

267. COD. PEN art. 204 (NEED YEAR) (Nicar.).

268. Morgan, supra note 2 , at 461. 
clearly intended to decriminalize heterosexual sodomy. ${ }^{269}$ The original provision as Section 205, identified as a crime concubinage between persons of the same sex or against nature, while the revised Article specifies that, in order to be criminal, sodomy must take place between persons of the same sex. ${ }^{270}$ In many ways, this removal of sodomy between heterosexuals from the prohibition and the clear specification of the crime as requiring two members of the same sex mirrors the United States' initial criminalization of sodomy through state statutes enacted in the early 1970s. ${ }^{271}$ The new Code further discriminates against homosexuals by deleting Article 206 of the 1974 Penal Code, which required that all individuals behave in a manner not offensive to "modesty or good customs by seriously scandalous acts not otherwise expressly penalized" or be subject to a sentence of up to two years imprisonment. ${ }^{272}$

The biggest and most noticeable change in the provision is clearly the addition of the language prohibiting the "inducing, promoting or propagandizing" of such behavior. ${ }^{273}$ Considering the highly "closeted" (referring to gay and lesbian individuals not open with the identification of their sexual orientation) nature of Nicaraguan society, the response to this portion of Article 204 was impressive. ${ }^{274}$ Over four thousand signatures were gathered petitioning President Chamorro to veto this section of the bill. ${ }^{275}$ Although counsel for the President, Antonia Lacayo, assured the community that "nobody wants a [witch hunt]," the provision was approved in its entirety. ${ }^{276}$

Curiously, the periodical publishing the new law was dated September 9 , 1992, but it was not issued until late October, 1992. ${ }^{277}$ The late publication "appeared perilously close to the end of the sixty day period for filing constitutional challenges to new legislation by way of recurso por inconstitucionalidad." 278 Nonetheless, a challenge to the provision was filed with the Nicaraguan Supreme Court on November 9, 1992. ${ }^{279}$

The recurso challenged the provision on the grounds that it was unconstitutional. ${ }^{280}$ In doing so, it put forth that the provision violated various sections of the Constitution which allowed for individual liberty, respect for the private lives of individuals and their families, and for their honor and reputation, contained in Article 25, Section 1, and Article 26, Sections 1 and 3, respectively. ${ }^{281}$ The recurso also looked to Article 46 of the Constitution,

269. Id. at 462.

270. Id. at 463 .

271. See generally Part II.

272. Morgan, supra note 2, at 463.

273. Id. at 462.

274. Id. at n.92.

275. Id. at 464 .

276. Id. at 464-65.

277. Id. at 465 .

278. Review for unconstitutionality. $I d$.

279. Id. at 466 .

280. Id.

281. Id. The recurso also looked to sections of the Constitution guaranteeing equality 
which "expressly incorporates and protects international human rights as established in [a variety of Declarations of Human Rights]."282

Prior to deciding the recurso, the Nicaraguan Supreme Court asked for commentary and guidance from President Chamorro. ${ }^{283}$ She indicated that it was the Court's responsibility to resolve any legal problems once the law was promulgated. $^{284}$ Others were not as reluctant to comment on the law. ${ }^{285}$ Alfredo Caesar, President of the National Assembly, requested that the challenge be rejected for failure to comply with the requirement that the challengers describe the prejudice, either direct or indirect, caused by the law. ${ }^{286}$ He went on to state that the law did not prohibit sodomy, but rather its "inducement, promotion, propagandizing or practice in a scandalous manner" and that the "sin is the scandal." 287 Regarding the recurso's reference to international human rights declarations incorporated in the Constitution, Cesar

before the law, the legality of crimes and punishments, respect for the physical, psychological and moral integrity of persons, the prohibition of torture and cruel, inhumane, or degrading proceedings, punishment or treatment and freedom of expression and information under Articles 4, 27, 48; Article 34(10); Article 36; and Articles 30, 66, 67 and 68. Id.

282. Id.

The Universal Declaration of Human Rights provides for: a right to liberty; right to the security of a person; equality before the law; the principle of legality of crimes and punishments; respect for the private life of persons and their family, and for their honor and reputation; liberty of thought; liberty of expression. It prohibits torture, cruel, inhuman or degrading punishment or treatment.

The American Declaration of Rights and Duties of Man provides for: the right to the liberty and security of the person; equality before the law; liberty of opinion, expression and diffusion of thought, protection of the private and family life of persons and their honor and reputation.

The International Covenant on Civil and Political Rights provides for: Respect and guarantee of the rights recognized in this Covenant for all persons, without any distinction; right to liberty; right to personal security; the principle of legality of crimes and punishment; respect for the private life of persons and their family, and for their honor and reputation; liberty of thought; liberty of expression; and equality before the law. The Covenant prohibits torture and cruel, inhuman or degrading punishments and treatments.

The American Convention on Human Rights (San Jose Pact) provides for: respect for the rights and liberties recognized in this Pact for all persons without any discrimination; right to respect for the physical, psychological and moral integrity of persons; right of liberty and personal security; the principle of legality of crimes and punishments; right to respect for the private life of persons and their family, and for their honor and reputation; right to liberty of thought and expression; and equality before the law.

Id. (citing Recurso Por Inconstitucionalidad, La Ley No. 143, "Ley de Alimentos," May 22, 1992, at 28-29).

283. Id. at 467.

284. Id.

285. Id.

286. Id.

287. Id. at 467-68. 
stated that "these are not on point because they are inspired by different moral conceptions than those that dominate our society." 288

The Procurado General de Justicia, Guillermo Vargas Sandino, also commented upon the challenge as well, pointing out that adults freely practicing "their sexual activity" (presumably homosexual relations) do not violate the Penal Code however "immoral and ... repugnant" such activity might be. ${ }^{289}$ Vargas also cited the Constitution in order to defend the sodomy law, citing Article 24, which provides that "the rights of each person are limited by the rights of others, for the security of all and for the just exigencies of the common good." 290

During the debates over the sodomy provision, the leader of the Revolutionary Unity Movement, Moises Hassan, described homosexual conduct practiced in a "scandalous manner" as:

[W] hen, in the streets of New York or of whatever North American city, hundreds of homosexuals march claiming "gay power". ... How can this be permissible? Here we must have a law that prevents that any day one hundred of these people who have the right to be what they are, but do not have the right to make this ostentatious. This is what is immoral, to make it ostentatious, a hundred people that march in the streets in front of your house, in front of mine, in front of a school saying "poder de los maricas" [gay power] ... ! That is scandalous in the society, that is an example of scandal. ${ }^{291}$

Ultimately, the Supreme Court rejected all challenges to the law on March 7, 1994. ${ }^{292}$ The Court addressed the challenger's arguments in only the most "cursory" of responses and denied that any of the constitutional provisions cited in the recurso were relevant to the case at hand. ${ }^{293}$ The Court stressed that the provision did not discriminate against the liberty of expression since the phrase "in a scandalous form" limits the sodomy provision. ${ }^{294}$ The Court then turned to a long defense of the institution of the family and stated in its opinion:

To authorize the functioning and liberty of sodomy would be a legal attack against the growth of the Nicaraguan population, a move backwards in its political, economic, and social advances, due to the lack of men and women to push ahead

291. Id. at n.96 (citing Aprueban caceria a homosexuales, BARRICADA INTERNACIONAL, June 12, 1992, at 1 ).

292. Id. at n.122.

293. Id. at 469.

294. Id. at 470 . 
the progress of Nicaragua .... To accept the arguments of the
challengers would be equivalent to authorizing the practice of
sodomy and as a consequence destroying the noble purposes
of marriage.

The Court further stated that "[t]o authorize the performance and freedom of sodomy would be a legal attack against the increase of the Nicaraguan population, a step back for its political economic and social advancement, due to the lack of men and women to push Nicaragua's progress forward."296 The Court concluded with the comment that "rather than protecting sodomy, ways should be found to limit it."

Upholding Article 204 had two effects, one expected and one likely not. $^{298}$ Rather than immediately chilling the gay population of Nicaragua, the passing of the law brought the gay community "out of the closet and into the public spotlight to an unprecedented degree" and began the shaping of the gay population of Nicaragua into a more organized political movement, the effect of which has yet to be seen. ${ }^{299}$ However, for some members of the gay community who were less willing to be open about their sexual orientation, the "law and the publicity surrounding it clearly had an intimidating effect." 300

The initial effect of the new law was as expected, an increase in the stigmatization toward Nicaraguan gays and lesbians. ${ }^{301}$ For example, one young homosexual man, after being attacked by an assailant, stated:

We do not know where to turn, if we go to the police, instead, we could be taken prisoner for being what we are .... The law does not protect us, it is as if we were [sic] not human beings now that they have denied us our rights." ${ }^{302}$

In a succinct commentary, journalist Sofia Montenegro described the failures of the effort to reform the penal code with respect to the rape laws and the sodomy laws, by saying simply

The two faces of patriarchal reaction, misogyny ... . and homophobia . . have conspired within the deputies, independent of their sex, sexual orientation, or party, to

295. Id. at 469-70.

296. The International Lesbian and Gay Association, World Legal Survey - Nicaragua, at http://www.ilga.info/Information/_egal_survey/americas/nicaragua.html (last updated Jul. 31, 2000) (last visited Oct. 21, 2004).

297. Id.

298. Morgan, supra note 2, at 476.

299. Id. at 477.

300. Id. at 480 .

301. Id. at 478 .

302. Id. 
produce this juridical-penal perversion that violates the rights of citizens. With a parliament like this, who needs legislators? ${ }^{303}$

It is too soon at this juncture to evaluate the effect that the sodomy laws will have on the gay and lesbian population of Nicaragua. Some believe that there is no intention to actually enforce the sodomy provision of the law, but that it is merely intended to remind the gay community that it does not have the moral approval of the majority of the Nicaraguan population. ${ }^{304}$ On the other hand, the provision may only further imbed the traditional heterosexist values propagandized by a culture dominated by Roman Catholicism and machismo.

\section{TREATMENT OF HOMOSEXUALS AND HOMOSEXUAL ACTIVITY IN THE INTERNATIONAL ARENA: A FEW COMPARISONS}

In considering the similarities and differences between the policies of the United States and Nicaragua it is helpful to consider the attitudes of various countries in the international arena. There are a variety of methods that countries of the world are using to address the treatment of homosexual activities in their homelands. Policies toward the homosexual community cover a broad spectrum.

\section{A. The Extreme End of the Spectrum: Iran and Saudi Arabia.}

Iran and Saudi Arabia operate at an extreme end of the spectrum. Both countries still execute individuals for engaging in homosexual activity. ${ }^{305}$ In 1987, the Iranian Embassy wrote in The Hague that "homosexuality in Iran ... is a $\sin$ in the eyes of God and a crime for society. In Islam generally homosexuality is among the worst possible sins you can imagine." 306 Iran allows a religious judge to sentence a gay man to death for one act of sodomy. ${ }^{307}$ Lesbians receive treatment that is slightly less harsh. ${ }^{308}$ They are punished with one hundred lashes for the first three offenses and, after the fourth offense, are subject to death by stoning. ${ }^{309}$ Amnesty International reported that in January, 1990, three gay men and two lesbians were publicly

303. Id. at 477.

304. Id. at 480.

305. John A. Russ, IV, The Gap Between Asylum Ideals and Domestic Reality: Evaluating Human Rights Conditions for Gay Americans by the United States' Own Progressive Asylum Standards, 4 U.C. DAVIS J. INT'L L. \& POL'Y 29, 35 (1998).

306. The International Gay and Lesbian Association, World Legal Survey - Iran, at http://www.ilga.info/Information/Legal_survey/middle\%20east/iran.htm (last updated Jul. 31, 2000) (last visited Oct. 21, 2000) [hereinafter Survey - Iran].

307. Russ, supra note 305 , at 35 .

308. Id.

309. Id. 
beheaded as a result of the government's anti-homosexual policy. ${ }^{310}$ On November 12,1995, another man was condemned to death for "the obscene act of sodomy" and was executed by stoning. ${ }^{311}$

The policy in Saudi Arabia is similar to that in Iran. ${ }^{312}$ Again, homosexual acts are illegal and are subject to the death penalty. ${ }^{313}$ A married man must be stoned to death, while a "free bachelor" is subject to one hundred lashes and banishment for a year. ${ }^{314}$ While there is no specific discussion of treatment of lesbians under Saudi Arabian law, Islamic law considers sexual activity between women as adultery, administering the death penalty by stoning for married women and one hundred lashes to unmarried women. ${ }^{315}$ In 1997, the religious police "frequently" arrested men for participating in homosexual activity. ${ }^{316}$

\section{B. Technically Legal, but Still Punished: China and Brazil}

With the advent of the "open door" policy in China in 1980, the "taboo" on homosexuality in China became less prevalent. ${ }^{317}$ Both the legal system and society as a whole in China have become more accepting of homosexuality in the past decade. ${ }^{318}$ However, at the 1995 International Gay and Lesbian Association's Annual Conference in New York City, a gay man from China shared that if a homosexual is "found out" in his country there is much to fear. ${ }^{319}$ For example, in China, it is still considered acceptable to use not only herbal treatments, but also electrodes, to "cure" homosexuals. ${ }^{320}$ Homosexuality in China may also still be punished under the term "hooliganism." 321 "A 'hooliganism' conviction commonly leads to jail time and 're-education' for gay men and lesbians."322

310. Survey - Iran, supra note 306.

311. Id.

312. Russ, supra note 305 , at 35.

313. The International Lesbian and Gay Association, World Legal Survey - Saudi Arabia, at http://www.ilga.info/Information/Legal_survey/middle\%20east/Saudi_Arabia.htm (last updated Jul. 31, 2000) (last visited Sept. 6, 2004).

314. Id.

315. Id.

316. Id.

317. The International Lesbian and Gay Association, World Legal Survey-China, at http://www.ilga.Info/Information/Legal_survey/Asia_Pacific/china.htm (last updated Jul. 31, 2000) (last visited Sept. 27, 2004) (citing excerpts from a speech by HIV activist Wan Yan Hai at the People's Summit, Vancouver, Nov. 1997) [hereinafter Survey - China].

318. Id. "[T]he nineties has become the 'coming-out' time for gays and lesbians in China. At the same time the government and the society have also become more tolerant for sexual minorities." Id.

319. Kevin Reuther, Queer Rights are Human Rights: Thoughts from the Back of a Cab, 8 HARV. HUM. RTS. J. 265, 267 (1995).

320. Russ, supra note 305 , at 39 .

321. Survey-China, supra note 318.

322. Reuther, supra note 320 at 267 . In response to the audience's questions about 
Despite some advances in China in the past two decades, homophobia and discrimination against homosexuals continue to be prevalent. ${ }^{323}$ Although it is no longer illegal to represent homosexuality in the media, it is often discouraged. ${ }^{324}$ During 1996, the Ministry of Propaganda refused to publish articles and books about homosexuality on more than one occasion, and in 1997, the Chinese government refused to allow movie director, Zhang Yuan, to accompany his film about homosexuals to the Cannes Film Festival. ${ }^{325}$

Brazil decriminalized most homosexual activity in $1823 .^{326}$ Yet homosexuality is still considered illegal in the Armed Forces of Brazil. ${ }^{327}$ However, the "police use the pretext of 'safeguarding morality and public decency' and 'preventing outrageous behavior' to stop, arrest, and bring gays to trial." "28 While Brazil removed homosexuality from the list of "psychological disturbances" in 1985, parents can still take their children to medical providers for "behavior-modifying" treatments without any legal recourse. ${ }^{329}$

\section{Improving, with More Room for Improvement: The Gay Community in Russia}

Russia has created a roller coaster ride for its gay community. From the period of 1917 to 1933 , homosexuality was decriminalized, but in 1934 was "recriminalized" and "severely dealt with by persecution, discrimination and silence." 330 Russia officially decriminalized sodomy in 1993 , but prior to 1993 , as many as 600 tol,200 homosexual men were sent to prison each year in the Soviet Union as a result of homosexual activity. ${ }^{331}$ Homosexual activity was punishable under Article 121.1 of the criminal code by imprisonment of up to five years. ${ }^{332}$

With the repeal of Article 121.1, those held in prison under the Article should have been released immediately. ${ }^{333}$ However, "[d]ue to the chaotic

whether or not the young man feared the cameras and videotapes at the conference, he declared "I am not afraid" and the audience responded with "applause and then fell anxiously silent." Id.

323. Survey - China, supra note 317.

324. Id.

325. Id.

326. The International Lesbian and Gay Association, World Legal Survey-Brazil, at http://www.ilga.info/Information/Legal_survey/americas/brazil.htm (last updated Jul. 31, 2000) (last visited Sept. 27, 2004).

327. Id.

328. Id.

329. Russ, supra note 305 , at 40 .

330. The International Lesbian and Gay Association, World Legal Survey-Russia, at http://www.ilga.info/Information/Legal_survey/europ/russia.htm (last visited Sept. 27, 2004).

331. Russ, supra note 305, at 43.

332. The International Lesbian and Gay Association, World Legal Survey-Russia, at http://www.ilga.info/Information/Legal_survey/europ/russia.htm (last updated Jul. 31, 2001) (last visited Oct. 21, 2004) [hereinafter Survey - Russia].

333. International Gay and Lesbian Human Rights Commission, Russia's Anti Sodomy Law Repealed, at http://www.iglhrc.org/site/iglhrc/section.php?id=5\&detail=357 (Aug. 1993) (last visited Sept. 27, 2004). 
prison system in Russia, it isn't clear that the government will know who or where these hundreds, perhaps thousands, of prisoners are." ${ }^{\text {,334 }}$ When a human rights delegation attempted to speed the release of prisoners held under Article 121.1, "many officials were unwilling to help," with one official quoted as saying, "I don't care what has been repealed. They're still in there and they will stay in there." 335

A poll of the Soviet Union's population taken in 1990 "showed that a third of the population ... believed that homosexuals should be exterminated, a third believed [they] should be isolated from society and only 10 percent believed [they] should be left alone." ${ }^{336}$ However, there has been progress towards acceptance of the homosexual community in Russia since the decriminalization of homosexual activity in $1993 .{ }^{337}$ During a governmentsponsored conference in Moscow entitled "The Family on the Eve of the Third Millennium," a discussion regarding same-sex marriage was held and the "recommendation to legalize such unions was taken without contradiction.,"338 A greater indication of progress occurred during a 1994 survey similar to the one taken in 1990 , in which the Russian population reported that only $18 \%$ wished to "liquidate" homosexuals, while the percentage of those wishing to "leave them by themselves" rose from $12 \%$ to $29 \%$. ${ }^{339}$

\section{Countries that Embrace Their Gay Communities: Denmark, the Netherlands, South Africa, and Canada.}

Other countries in the international community have been much less reluctant to embrace their homosexual communities. In Europe as a whole, it has been noted that:

There is now a better understanding, and in consequence an increased tolerance, of homosexual behavior to the extent that in the great majority of the member-States of the Council of Europe it is no longer considered to be necessary or appropriate to treat homosexual practices of the kind in question as in themselves a matter to which the sanctions of the criminal law should be applied. ${ }^{340}$

334. Id.

335. Igor Kon, Moonlight Love: Problems and Prospects, Russian National GLBT, at http://www.gay.ru/english/history/kon/prosp.htm (1998) (last visited Oct. 21, 2004) [hereinafter Moonlight Love].

336. Ryan Goodman, The Incorporation of International Human Rights Standards into Sexual Orientation Asylum Claims: Cases of Involuntary "Medical" Intervention. 105 YALE L.J. 255, 277 (1995).

337. Moonlight Love, supra note 335.

338. Id.

339. Id.

340. Larry Cata Backer, Inscribing Judicial Preferences Into Our Fundamental Law: On 
Denmark and the Netherlands may be the European counties best known for embracing their gay communities. Denmark enlarged its law to forbid discrimination on the basis of sexual orientation in $1987 . .^{341}$ The law provides that any person discriminating on the basis of sexual orientation is subject to punishment by "fines, short-term detention or imprisonment for up to six month[s]." 342 In 1996, this law was expanded to include the private labor market. ${ }^{343}$ Additionally, Denmark expanded its "anti-vilification" law in 1987 to provide that "[p]ersons who publicly or deliberately disseminate statements or other reports by which any group of people are threatened, ridiculed or degraded on account of their ... . sexual orientation, are liable to fines, shortterm detention or imprisonment for up to two years."

What Denmark may be best known for is its pioneering in the matter of same-sex unions. $^{345}$ In 1989 Denmark became the first country in the international community to introduce a law on registered partnerships for samesex couples. ${ }^{346}$ The couples are granted the same rights as married heterosexuals with a few exceptions. ${ }^{347}$ The same divorce laws that apply to heterosexual couple also apply to partners in a registered partnership. ${ }^{348}$

The Netherlands is also a positive environment for its homosexual community. Dutch criminal law no longer contains any provisions outlawing homosexual activity. ${ }^{349}$ While the Dutch Constitution does not specifically name homosexuals as a protected class, "discrimination against homosexuals is forbidden by the Constitution owing to parliamentary documents and legal precedent which place sexual orientation under the protection of the first article of the Constitution." 350 In 1992, the terms "homosexual and heterosexual orientation" were added to the articles providing criminal protection from discrimination. ${ }^{351}$ Finally, in 1994, the General Equal Treatment Act was passed prohibiting discrimination in the fields of housing, medical care, labor,

the European Principle of Margins of Appreciation as Constitutional Jurisprudence in the U.S., 7 TUlSA J. COMP. INT'L L. 327, 357 (2000).

341. The International Lesbian and Gay Association, World Legal Survey-Denmark, at http://www.ilga.info/Information/Legal_survey/europe/denmark.htm (last updated Jul. 31, 2000) (last visited Sept. 27, 2004).

342. Id.

343. Id.

344. Id.

345. Id.

346. Id.

347. Id. The exceptions for a registered couple are that they are unable to adopt children from a foreign country although they can adopt children of their partners. They are unable to be wed "officially" in a church and either one of the partners must be a registered citizen of Denmark or both members of the partnership must have stayed in Denmark for two years. Id.

348. Id.

349. The International Lesbian and Gay Association, World Legal Survey-The Netherlands, at http://www.ilga.info/Information/Legal_survey/europe/netherlands.htm (last updated Jul. 31, 2000) (last visited Sept. 27, 2004).

350. Id. (emphasis omitted).

351. Id. 
and access to goods and services on the grounds of, among other things, an individual's sexual orientation. ${ }^{352}$

South Africa became the first country in the world to "enshrine lesbian and gay rights in its Constitution" under Clause 9(3) which reads: "The state may not unfairly discriminate directly or indirectly against anyone on one or more grounds, including . . sexual orientation ...., ${ }^{353}$ In October, 1998, the Constitutional Court confirmed that laws prohibiting sexual activity between two men were unconstitutional. ${ }^{354}$ In December, 1999, the High Court confirmed a previous ruling that the Aliens Control Act discriminated unfairly against lesbian and gay couples by denying them rights available to married heterosexuals and stated, "[g]ays and lesbians in same-sex life partnerships are as capable as heterosexual couples of expressing ... love in its manifold forms ... they are capable of constituting a family ....,355

Finally, in 2003, Canada, the country geographically closest to the United States to do so, legalized same-sex marriage in the Canadian province of Ontario. The Ontario Court of Appeals upheld an earlier ruling establishing the right to marriage for homosexuals and "ordered same-sex marriage legalized in the province immediately." 356 In its opinion, the Court of Appeals "unanimously dismissed the idea that procreation and rearing children mandate the exclusion of gay and lesbian couples from the institution of marriage" as the "ability to 'naturally' procreate and the willingness to raise children are not prerequisites of marriage for opposite-sex couples."357

\section{CONCLUSION}

It is apparent that the United States and Nicaragua have vastly differing approaches to the treatment of homosexual activity practiced by consenting adults. Both countries are willing to allow certain homosexual sexual practices to occur as long as they are done in private. However, the reasoning behind this conclusion that such activity is permissible in private is extremely different.

The United States has based its decision not to prosecute sodomy upon the idea that there is a sphere of privacy surrounding the bedroom, which cannot be intruded upon by the State. ${ }^{358}$ The United States concludes that to violate that sphere of privacy only in the instance of homosexual citizens would

352. Id.

353. The International Lesbian and Gay Association, World Legal Survey-South Africa, at http://www.ilga.info/Information/Legal_survey/Africa/southafrica.htm (last updated Jul. 31, 2000) (last visited Oct. 21, 2004). This amendment to the Constitution was included on May 8 , 1996. Id.

354. Id.

355. Id. The Alien Control Act monitors immigration to South Africa. Id.

356. Ann Rostow, Toronto declares gay marriage legal, PlanetOut News \& Politics, at http://www.planetout.com/news/article.html?2003/06/10/1 (Jun. 10, 2003).

357. Id.

358. Lawrence v. Texas, 539 U.S. 558 (2003). 
be to deny citizens a right without a sufficiently compelling interest of the State. ${ }^{359}$

The United States remains, however, only willing to grant homosexual citizens rights pertaining to their exercise of sexuality within the bedroom. As of yet, the United States has refused to allow other rights enjoyed by heterosexual couples to extend to homosexuals. The most obvious example of this is the United States' refusal to sanction gay marriage. ${ }^{360}$

Nicaragua, by contrast, is also willing to permit homosexual conduct to take place in private, as long as such conduct does not create a scandal. ${ }^{361}$ However, Nicaragua's reasoning behind this continues to be a desire to keep homosexual citizens out of the eyes of the populace in order to prevent offense to the majority of the citizens of the country. ${ }^{362}$ Rather than seeking to protect the rights of homosexuals, Nicaragua is more concerned with limiting them as much as reasonably possible without making the existence of homosexuality itself illegal. ${ }^{363}$

The irony is, of course, that the legal outcome of these two approaches, despite the different reasoning behind them, is not terribly different. While homosexual citizens of the United States can certainly be more relaxed while exercising their right to seek liberty and sex, as they desire, they, like homosexual citizens of Nicaragua, are forced to endure the knowledge that the majority of the population and the legal system would prefer to hear no more about it than necessary.

359. See supra Part II.E.

360. See Singer v. Hara, 522 P.2d. 1187 (Wash. Ct. App. 1974); Standhardt v. Superior Court of Ariz., 77 P.3d. 451 (Ariz. Ct. App. 2003). Both courts held that it was not unconstitutional to deny same-sex couples the right to marry.

361. Morgan, supra note 2, at 468.

362. Id.

363. See id. at 470. 
